\title{
CHANGING PROPERTY REGIMES IN MĀORI SOCIETY: A CRITICAL ASSESSMENT OF THE SETTLEMENT PROCESS IN NEW ZEALAND
}

\author{
TOON VAN MEIJL \\ Radboud University Nijmegen
}

Since the early 1990s, New Zealand has been engaged in a political process that aims to settle the grievances of the country's indigenous Māori population about the colonial history of dispossession and alienation. The settlement process in New Zealand marks a positive turning point in the relationship between Māori and Pākehā (the descendants of European settlers), but has also shown that Māori grievances cannot be resolved unambiguously. In the course of the settlement process new, unforeseen problems have come to the fore, which have made it apparent that justice and reconciliation can not be seen as easy policy targets, but instead as part of an ongoing process of negotiations.

The settlement process in New Zealand is extraordinarily complex, but for analytical purposes it may be argued that it is hampered for two fundamental reasons. First, the government has decided to negotiate settlements only with tribal organisations, whereas more than 80 percent of the Māori population is currently living in urban environments where the meaning of tribal connections has changed considerably. The central position of tribes in the settlement process is therefore contested by pan-tribal groupings in cities, who also want to benefit from the resources that the government is transferring back to Māori ownership in compensation for Māori dispossession in the 19th century. Second, the socio-political organisation of Māori society has changed radically since the 19th century, which raises the question of representation for descendants of the Māori who were originally dispossessed. In many regions, local sub-tribes (hapu) are challenging the centralised structures of governance implemented by tribes ( $i w i)$ or even super-tribes (waka) that have signed compensation settlements with the government on the assumption that they represent the entire confederation of lower ranking units in the tribal hierarchy. The underlying question in these disputes is who used to own what and when? This raises a more fundamental question about the nature of property rights in the 19th century. Who used to own the land and other resources: extended families (whänau), sub-tribes, tribes or super-tribes? Subsequently, the issue of who are the rightful heirs of the original owners may be addressed. 
In this article I seek to address these questions from the perspective of legal anthropology in order to disentangle the problem of ownership in postsettlement Māori society. My argument is that contemporary Māori property rights are inherently ambiguous because both property regimes and property relations in Māori society have changed fundamentally since the beginning of colonisation in the 19th century. This ambiguity will necessarily have to be reflected in any political settlement of their colonial grievances. I begin with a more detailed overview of the problems that have come to light in the course of the settlement process.

\section{THE PROBLEM OF THE SETTLEMENT PROCESS}

New Zealand is usually portrayed as a country that has managed to balance interethnic relations between Māori and Pākehā comparatively well. Behind this widely repeated cover story, however, lie ethnic problems that may be denied, excused or sometimes ruefully acknowledged. One of these problems may be summarised as follows: Māori demands for self-government are intensifying as they claim that in the global era their right to express themselves culturally is increasingly in danger (Sharp 1997a: 423-4). Māori concerns are intertwined with their over-representation in the lower socioeconomic brackets, which, in turn, is argued to be the result of the colonial history of dispossession and the denial of reparative justice. This paper is concerned only with the justice component of the so-called "Maori problem" (Sharp 1997a: 423) of New Zealand.

In the 1990s, the New Zealand government gradually began to compensate for past wrongs by providing reparations to Māori and also by allowing them more autonomy in managing their own affairs. The process of redressing Māori grievances follows a gradual recognition of the Treaty of Waitangi, a pact that was originally signed between the British Crown and Māori chiefs in 1840 (Orange 1987). By signing the Treaty, Māori chiefs ceded 'governance' (kawanatanga), whatever that meant in those days, in exchange for the retention of their lands, forests, fisheries and other resources. In the course of history the legal status of the Treaty, however, was not recognised and thus the covenant simply legitimated the colonisation of New Zealand and the dispossession of Māori. Since the late 1960s, however, the tide has gradually been turning. Since the second half of the 1980s, it may even be suggested that the Treaty is increasingly accepted as a document that can no longer be neglected (Belgrave, Kawharu and Williams 2005, Kawharu 1989a, McHugh 1991). In the early 1990s, an irreversible reconciliation process was initiated, aimed at repairing the historical error of denying the Treaty (Ward 1999). Thus, paradoxically, New Zealand began playing an exemplary role in settling colonial grievances and attempting to provide justice to the country's indigenous population. 
After some ten years or more, however, it is becoming increasingly apparent that redressing Māori grievances is far from easy. Some people would even argue that the settlement process is creating chaos in what used to be a relatively peaceful country in the South Seas. Not surprisingly, the most critical comments regarding the settlement process are made by non-Māori, who vigorously dispute the right of the indigenous population to what they consider as common resources. This critique arises from ignorance of the history of dispossession, which has only partly been corrected over the past two or three decades. Revelations of the country's colonial history, however, seem only to have redirected non-Māori criticism of the settlement process. Currently the vast majority of the New Zealand population would probably endorse the need to repair past wrongs, but many are also inclined to think that the government is transferring too many resources to obscure Māori tribes too fast. As the number of claims expanded up until the 2008 deadline for the submission of claims, conservative politicians still advocated that what they label as "the Treaty industry" must be stopped and that all historic Treaty claims be resolved within the next five years or so. Needless to say, this is by no means realistic.

Interestingly, however, not just conservative politicians or citizens express their doubts about how the government is managing the settlement process. Critical intellectuals, too, have some misgivings about the contemporary direction of the public opinion in inter-ethnic New Zealand. The social anthropologist Erich Kolig (2004), for example, has questioned the sense of liberal guilt about the colonial past. He suggested that it has generated an atmosphere of political correctness keeping many non-Māori New Zealanders in fear of critically assessing the ever expanding demands of Māori groupings as they become more influential after an impressive series of legal victories in recent history (see also Bell 2004). At the same time, the noted historian Bill Oliver (2001) wrote an astute analysis of the revisionary history of New Zealand presented in the reports of the Waitangi Tribunal, which had been set up to examine Māori claims and to make recommendations to the government for redress. Oliver argued compellingly that the investigations of the Waitangi Tribunal are guided too much by present discontentment about the marginal position of the Māori population and that this colours their instrumental interpretation of the historical evidence. In turn, this leads to the creation of a retrospective utopia in order to propose a plausible strategy to resolve the deprivation of the Māori (see also Belgrave 2005, Byrnes 2004).

The process of settling Māori grievances, however, is not only controversial among non-Māori, but also within Māori society itself. The most contentious issue concerns the distribution of returned resources among Māori (Barcham 2007). The question to whom resources should be returned in Māori society 
surfaced most clearly in the debate about the distribution of Māori fisheries after the government in 1992 made available a significant amount of money to buy fishing quota for Māori people. Subsequently, it took some 14 years of litigation to decide whether the quota should be distributed exclusively among tribes or whether pan-tribal organisations, mainly in cities, were also eligible for a share (Webster 2002). Eventually, a compromise was reached and urban organisations did receive some acknowledgement, but in the end all participants in the debate lost some advantage in the process (Van Meijl 2006).

Another interesting case related to the discussion about the central role of tribes (iwi) is the claim of the Waipareira Trust in Auckland that it also constitutes (an) iwi (Sharp 2003). In view of the fact that more than 80 percent of the Māori population is currently living in cities, it cannot be surprising that organisations have emerged to represent urban Māori communities. Since the late 1980s, these model themselves increasingly after the so-called "traditional" tribal organisations in Māori society. The motivation behind this "modern tradition" is directly derived from the government policy of decentralisation and devolution of administrative functions to community organisations. As part of this process the Department of Maori Affairs was also abandoned and its budget and resources were transferred to Māori tribes. In this context, urban organisations also wanted to become eligible for these resources in order to provide services to the Māori population in cities. Hence they argued that they were "urban tribes" (Waitangi Tribunal 1998).

The controversy between "traditional" tribes and so-called urban tribes (or, more correctly, pan-tribes) about the government's policy of settlement revolves partly around the question of what exactly the aim of the settlement policy should be: historical justice by returning resources that were unjustly dispossessed in the 19th century, or social justice by redistributing resources among those who suffered most from colonisation (Lashley 2000, Sharp 2004: 198-200). In New Zealand this debate parallels the interpretation of the Treaty, which guarantees Māori proprietary interests in Article Two, but also pledges to Māori the benefits and privileges of citizenship in Article Three (see below). Depending on their interests, different sections of the Māori population focus either on Article Two, mainly tribes, or on Article Three, mainly pan-tribes.

Although in practice the disagreement between tribes and pan-tribes about the settlement process is much more complicated, it is beyond the scope of this article to elaborate on the implications of this dispute. Instead, the focus of attention here will be on the differences of opinion within tribes about the internal distribution of returned resources and additional compensation funds. The two largest settlements signed in the 1990s may illustrate these differences. In 1995, the Waikato-Tainui tribes received the first major settlement from the government, which has been controversial from the outset. 
Many groupings disputed the right of the tribal leadership to represent them and demanded autonomy, but the government insisted on negotiating only with the tribal leadership and settling the claim over the entire tribal territory all at once. This division between the sub-tribal groupings, who specifically rejected tribal leaders' authority to represent them, and those tribal leaders lingered for many years after the settlement had been signed, and, indeed, many people continue to dispute the centralised structure of control within the tribe, headed by a monarchy (Muru-Lanning 2011, Van Meijl 2003a). The other major settlement with the South Island Ngāi Tahu tribe is often contrasted with the Waikato-Tainui, since Ngāi Tahu has overall been more successful in managing the resources it received from the government in compensation for its historical grievances. The apparent business success of Ngāi Tahu, however, eclipses a similar debate within the tribe about the construction of a central system of representation and governance that leaves local, sub-tribal groupings little space for autonomous manoeuvring (Waymouth 2003). Since Ngāi Tahu does not have its own kingship, the discussion surrounding the settlement within the tribe may not be as focused as the debate within Tainui, but the similarities between the two tribes are more striking in this respect than is usually acknowledged.

The controversies surrounding the settlements of Tainui and Ngāi Tahu are exemplary for many smaller and larger disputes that have surfaced within Māori tribal organisations in recent years (e.g., Hofmann 2009, Kahotea 2005). These raise the question of why the government has opted for a policy in which it negotiates settlements exclusively with tribes, not with sub-tribes. This question is even more interesting since this policy was introduced during the same year as the government abandoned the delivery of government services through tribal organisations in 1992 (Sharp 1997a: 442). The motivation behind the end of the devolution policy was that most Māori did not regard tribes as either traditional or as representative of the bulk of the Māori population living in cities. Why, then, does the government negotiate about the settlement of historical grievances only with tribes? Is it possible for the government, for example, to include sub-tribes or even extended families in the settlement process?

Since the central position of tribes in the settlement process is disputed, it is necessary to examine the evolution of tribal organisation in the colonial history of New Zealand in light of the question regarding the nature of property rights. A legal anthropological analysis of tribal relations in the past and present may clarify tribal disputes about ownership of land and other resources. Before moving on to set out an analytical framework for the analysis of changing property regimes and property relations in Māori society, however, I begin with a brief sketch of the historical background. 


\section{THE TREATY OF WAITANGI}

The so-called "Maori problem" (Sharp 1997a: 423) in New Zealand is invariably discussed in terms of the Treaty of Waitangi. Even though the Treaty was signed in 1840, it is increasingly cited with reference to all aspects of the relationship between Māori and the "Crown" since it received some recognition from the mid-1970s. Against the background of history this cannot be surprising.

Following the intensification of contact between Māori and European colonists, a governor was assigned to secure sovereignty for Britain, preferably by means of a treaty with the Māori people. On 6 February 1840, exactly one week after his arrival, Governor Hobson signed a treaty with a number of Māori chiefs in Waitangi (Orange 1987). The debate about the Treaty of Waitangi is complicated since there are significant differences between the English version and the Māori translation that was signed by most Māori chiefs. There can be no doubt that both signing parties had different understandings of key aspects.

The Treaty is made up of three articles. In Article One, the English version states that the chiefs ceded "all the rights and powers of Sovereignty" over their respective territories. The Māori version does not use the nearest equivalent to sovereignty, i.e., mana, but rather kawanatanga, a transliteration of 'governorship' improvised by the missionaries, which to Māori might not have meant more than the coming of the first governor. In Article Two, the English version guaranteed Māori "the full exclusive and undisturbed possession of their Lands and Estates Forests Fisheries and other properties". The Māori version of this clause was less specific yet all-embracing as it confirmed to Māori, according to Mutu's translation (in Matiu and Mutu 2003: 223, see also Kawharu 1989b: 319-20), "the unqualified exercise of their paramount authority over their lands, villages and all their treasures". In Article Three of the English version, the Queen of England promised to "protect all the ordinary people of New Zealand" [i.e., the Māori] and to give them "all the same entitlements [according to British law] as her people of England" (Matiu and Mutu 2003: 223; see also Kawharu 1989b: 319-20). This article appears less contentious, but was politically compromised by the ultimate goal of British colonisation: the amalgamation of the Māori people.

The signing of the Treaty of Waitangi marks the formal notification of the first steps towards comprehensive European control of the Māori and New Zealand society. It opened up the avenue for the arrival of growing numbers of European settlers, which made Māori people more reluctant to share their country with others. Ultimately, the tension between Māori and Europeans degenerated into a war in 1860 . Following a series of battles, three and one 
quarter million acres of land were confiscated in 1864 (Kawharu 1977: 1415). Outside the confiscated areas, New Zealand was brought under colonial control through the individualisation of customary land titles by allotting individual shares to a maximum number of ten owners of each block of land. As a corollary, many Māori people lost recognition of their interests and were dispossessed of their tribal lands.

The New Zealand Wars (1859-1864) and their aftermath were obviously in violation of the Treaty of Waitangi that guaranteed Māori proprietary rights. In order to settle their grievances over breaches of the Treaty, Māori people frequently appealed to the law in the 1870 s. Their experiences in court, however, demonstrated that the Treaty offered them no protection. A leading case in 1877 involved Wi Parata, the Western Maori Representative in Parliament, who in the Supreme Court requested that land issued to Bishop Selwyn of Wellington be returned to his tribe Ngāti Toa. In his judgement Chief Judge James Prendergast described the Treaty of Waitangi "as a simple nullity", because it had been signed "between a civilised nation and a group of savages". ${ }^{1}$ In his view, the Treaty had no judicial or constitutional status because Māori were not a nation capable of signing a treaty. Thus, this ruling dismissed Māori rights on the basis of the Treaty and set a precedent for all legal cases with which Māori attempted to secure redress through the courts until 1987. For 110 years the Treaty of Waitangi was consistently ignored by the British Crown and its legal representative, the New Zealand government, in spite of an unceasing Māori quest for acknowledgement of the Treaty (Orange 1987: 226-54).

In the 1960s the political climate in New Zealand changed steadily under the impact of the black civil rights movement in the United States. The Māori intensified their struggle for the recognition of the Treaty of Waitangi. In 1975 the government responded with the Treaty of Waitangi Act which established the Waitangi Tribunal. ${ }^{2}$ Section 6 of the Act allowed any Māori to submit a claim to the Tribunal on grounds of being "prejudicially affected" by any policy or practice of the Crown that was "inconsistent with the principles of the Treaty". The most important limitation of the act, however, was that "anything done or omitted before the commencement of (the) Act" was excluded from the Tribunal's jurisdiction. Māori could not therefore submit claims about their large-scale dispossession in the 19th century. In 1985, however, the newly elected Labour government led by David Lange provided for the extension of the Tribunal's jurisdiction back from 1975 to 6 February 1840 when the Treaty was signed. Needless to say, this clause opened up an important avenue for Māori people to seek redress for past grievances. However, the Tribunal can only make recommendations to the Crown, which remains the only authority to make compensation for or redress grievances. 
Towards the end of the 1980s some 600 claims had been submitted to the Waitangi Tribunal (Belgrave, Kawharu and Williams 2005) most of which had been sparked by the government policy of corporatisation, which involved a masssive transfer of lands and resources held in Crown ownership to semiprivate State Owned Enterprises. In response to a request from Māori tribes, however, the Court of Appeal ruled on 29 June 1987, that the transfer of assets to State Owned Enterprises would be unlawful without establishing any system to consider whether the transfer of particular assets would be inconsistent with the principles of the Treaty of Waitangi. It was the first time in New Zealand history that the legality of the Treaty was recognised.

\section{WHAT IS A MĀORI TRIBE?}

The recognition of the Treaty made it legally and politically inevitable to redress violations of the Treaty that had occurred in the past. During the second half of the 1980s, it became obvious that Māori tribal organisations were going to play a prominent role in the implementation of the settlement process. This followed the policy of the Labour government to address Māori concerns and to allow Māori people to put forward their own solutions. It organised a number of conferences in the mid-1980s, at which Māori tribal organisations from all over New Zealand argued for tribal control of resources and delivery of resources through tribal authorities (Fitzgerald 2004). For a number of reasons the government appeared willing to involve Mãori tribes in the delivery practice of social services through its policy of devolution. It argued that after 150 years of bypassing Māori networks, the time had finally come to recognise Māori tribal organisations and to respond to indigenous requests for self-management based on the bonds of kinship as embedded in "traditional" Māori society (Butterworth and Young 1990: 119-20).

Although the devolution policy did provide opportunities for Māori tribal organisations, it created a new, unprecedented problem for pan-tribal groupings in predominantly urban areas. They did not want the local, host tribes in cities and towns to become responsible for the social problems of urban centres largely populated by members of other tribes. For that reason, they began exploring the possibility of setting up their own "tribal authorities" in order to qualify for the implementation of government programmes and the delivery of social services.

In order to implement the policy of devolution the government introduced the Runanga Iwi Act in 1989. This Act was to enable the empowering of tribal authorities to administer government programmes formerly operated by the Department of Maori Affairs. It induced a discussion, however, about which tribal or chiefly authorities should be empowered to manage and administer community development programmes. Underlying this debate, however, 
were the more fundamental questions: what constitutes a tribal authority and what is a Māori tribe?

In anticipation of government legislation to enable tribal authorities to deliver social services, many Māori groups and organisations legalised their status by, for example, registering under the Charitable Trusts Act. Thus, they hoped to increase their chances of becoming recognised as tribal authorities under the forthcoming Runanga Iwi Act. The government indicated they would select only 12 or 15 tribal authorities but, over the next year or so, nearly 200 Māori organisations applied for the status of tribal authority. Among these organisations there was a marked distinction between urban and rural groups.

In rural areas many local communities refused to surrender their autonomy to some tribal authority at a higher level of their traditional hierarchical structure and applied for legal recognition of their autonomy. By the same token, many tribes were reluctant to recognise super-tribal authorities as the principal statutory authority to which they would be answerable about the implementation of devolution programmes. This tendency towards tribal division was paralleled in urban environments where a large number of autonomous Māori organisations emerged. Paradoxically, however, the main reason why pan-tribal organisations set up their own "tribal authorities" in New Zealand cities and some towns proceeded from their strong criticism of the tribal basis of the devolution policy. On the one hand, many people living in urban environments no longer wished to be represented by tribal organisations and therefore claimed their own share of the devolution programme (Waitangi Tribunal 1998). Tribal organisations and authorities, on the other hand, were hoping that the implementation of devolution would entice their lost relatives to return to where they were thought to belong.

As a result of the devolution policy, then, Māori society became deeply divided both between lower and higher ranking tribal organisations, and between predominantly rural based tribal organisations and predominantly urban based pan-tribal organisations (Van Meijl 1997). As rural and urban, tribal and non-tribal sections of the Māori population have gradually separated over the past 50 or more years, the political debate between tribal and pan-tribal organisations, which in the legal context both identify as "tribal authorities", complicates the anthropological and historical debate on the definition of tribe (Poata-Smith 2004).

The concept of tribe was gradually introduced in 19th-century discourse as an ethnographic gloss of the Māori concept of $i w i$, which literally means 'people' or 'bones'. As a translation of iwi, however, the concept of 'tribe' suggests a coherence that may well exceed the affinal ties within iwi (Metge 1986: 37). In view of the principles of ambilineal descent and ambilateral 
affiliation, the composition of tribes was rather loose and their articulation as a kinship grouping stemmed largely from the organisation of lavish feasts (Firth 1959: 139). As corporate groups, iwi may even be the result of postcontact developments, while the central unit within the socio-political organisation of Māori society was most likely the hapu, which is usually translated by the equally misleading gloss 'sub-tribe' (Van Meijl 1995).

In Māori discourse, moreover, neither the distinction between $i w i$ and $h a p \bar{u}$, between tribe and sub-tribe, nor the distinctions between all other lower and higher levels of the hierarchical structure of socio-political organisation, is clear-cut (Ballara 1998: 25-35). The concepts of tribe and sub-tribe are evidently structural, if not ideological, representations of highly dynamic kinship practices. Any understanding of Māori socio-political organisation should, therefore, give adequate weight to the fluid nature of the relationship between groupings. Māori kinship practices did not allow social relationships to be set in concrete. Tribal groupings mixed and divided, minor segments waxed while major segments waned, people migrated and formed fresh relationships, all causing Māori kinship groupings to be inherently flexible (Webster 1975: 124, see also Webster 1998: 124-52).

Following this logic it could be argued that over the past few decades new "tribes" have emerged among Māori communities in the urban areas of New Zealand. They are now demanding a fair share of the assets that the government is gradually transferring to Māori management and also to Māori ownership, following the settlement of historic violations of the Treaty of Waitangi. By the same token, it could be argued that "traditional" tribal organisations, which have been undermined and marginalised as a result of the massive migration of Māori to urban areas since the 1930s, should not be made more powerful than some of them became following the devolution of government resources. For similar reasons, it could be argued that it is not obvious that tribes represent all Māori people during the negotiations about redressing historic Māori claims regarding the violation of the Treaty of Waitangi.

Since these arguments could not be resolved unambiguously, the National government, which succeeded the Labour government in 1990, quickly decided to turn its back on devolution of services to tribes on grounds that tribes were neither necessarily traditional, nor represented automatically the large urban population. They repealed the Runanga Iwi Act in 1991, but, paradoxically, decided at the same time to extend the tribal basis of the devolution policy to a new policy for the settlement of Treaty of Waitangi claims. They entered into direct negotiations with tribes about the settlement of Māori grievances, a policy which was undoubtedly influenced by the impressive series of Māori victories in the courts during the second half of the 1980s. By the late 1980s, therefore, it had become increasingly evident 
that governments could be held hostage by Māori demands as interpreted by the Waitangi Tribunal and the courts. Since no government could contemplate this, particularly in times of economic crisis, the settlement of Māori grievances would have to be "political" rather than "legal".

In the mid-1990s when the settlement of land claims began, the National government also sanctioned in law its policy to negotiate directly and only with tribes. It amended the Treaty of Waitangi Act so that the Waitangi Tribunal could decline to hear claims not lodged and mandated by tribes (Department of Justice 1995, see also Sharp 1997b: 291-318). The aim of this move was simply to prevent individuals and smaller tribal groupings from making claims over collective assets without the authority of tribes. As mentioned above, this policy has meanwhile proved rather controversial. First, in urban environments where pan-tribal groupings are continuing to seek recognition in order to become eligible for the substantial amount of resources and compensation funds transferred back to Māori ownership. And second, within tribal confederations where lower ranking groupings, usually hapū or sub-tribes, are refusing to accept tribal control and management of resources that have been received by $i w i$ from the government in compensation for their specifically local unjust dispossession in the 19th century.

This controversy about Māori settlements within tribal organisations clearly raises the question of ownership. This seems the crucial issue of debate since different groupings hold different conceptions of property, which, in turn, is related to their different property relations. Surprisingly, however, few people have analysed the problems that have emerged in the settlement process from the perspective of legal anthropology on property relations. Pocock (2000) has argued that the injustices in Māori history have been caused mainly by the introduction of the capacity to alienate property with which the Màori were not familiar before the arrival of Pākehā. The introduction of a process of commodification in which all goods became mobile, in which Homo became mercator, and in which the nature of property was transformed from possession to alienability, Pocock (2000:30) contended, opened the future for Māori at the price of uncertainty. Māori found themselves living in a new world characterised by shifting patterns of possession, while the Treaty that was supposed to guarantee their authority became an instrument by which they lost it.

Elizabeth Rata $(2000,2003)$ is another New Zealand scholar who has analysed Māori contention about the settlement process in terms of misunderstandings about property relations. She also argued that property and ownership did not exist as concepts in the past, but the aim of her line of reasoning was to demonstrate that the recent recognition of tribes as the only owners of traditional resources is a prerequisite of the expansion of global capitalism in New Zealand. Her assumption that concepts of property 
and ownership are relatively new in Māori society, however, needs to be examined in the form of a detailed analysis of property relations in the past. This seems necessary also to assess the implications of historical property relations for the settlement process in the present. Before addressing these questions it is essential to determine first what property is and how it may be analysed adequately.

\section{AN ANALYTICAL FRAMEWORK FOR THE ANALYSIS OF PROPERTY RELATIONS}

In a recent volume on property and the transformation of property in the global economy, Caroline Humphrey and Katherine Verdery (2004: 1) remarked that property is "a protean idea that changes with the times". This viewpoint constitutes an interesting point of departure for any analysis of property, since it calls for a review of variations in the construction of property and property relations over the years. In its most basic form property is widely understood as a relation between people and things. Although the type of relation between people and things varies across cultures and has changed over time, since the Enlightenment the specification of property relations as private property rights has achieved dominance throughout the world (Hann 1998: 1). Over the past two centuries, property has in western legal thinking also been understood as intrinsically linked with the ideologies of economic development and liberal democracy. This may explain why currently rights and entitlements are emphasised in property discourses and why subjects of property relations are regarded as inherently rights-bearing (Humphrey and Verdery 2004: 5). The emphasis on rights in Western perspectives on property also clarifies that the focus of analysis should not be on the "things" over which people may claim more or less exclusive rights of ownership, but instead on the rights that people hold over things (Hann 1998: 4). In other words, property relations do not exist between persons and things, but between people in respect of things. Since people normally own rights to things instead of things as such, property relations should consequently be considered as social relations between people.

Stemming from these assumptions about the social nature of property relations it requires no further explanation that in view of the complexity of social organisation as documented in the ethnographic records of anthropology, property relations are multi-stranded. By the same token, property is not one specific type of right or relation such as ownership, but it is a blanket term that encompasses a wide variety of different arrangements, in different societies, and across different historical periods. For that reason, too, property rights have been thought of as a "bundle of rights" that stretch 
across several dimensions of human societies, including at least economic, political and legal dimensions. Although the conception of property as a bundle of rights has long been considered a useful metaphor for the analysis of property relations, the debate about property is often hampered by the ideological and reified dichotomy between individual property in the West and collective property in non-Western societies. In order to alleviate this bias, a more analytical understanding of property relations is required for the disentanglement of the various strands of property in any type of society. For this purpose, Franz and Keebet von Benda-Beckmann (1999) have developed a fruitful framework that is able to capture the complexities and manifold variations of property in different societies and in different periods of history, as well as the different functions that property may have. For that reason, too, it will be useful to elaborate their approach of property in more detail.

The main characteristic of the Von Benda-Beckmanns' approach to property is the distinction of property relations, in all their cross-cultural variations, at what they call four different "layers" of social organisation: cultural ideals and ideologies, more concrete normative and institutional regulation, social property relations, and social practices (Von Benda-Beckmann and Von Benda-Beckmann 1999: 22). The distinction between these layers is, of course, analytical since these dimensions of social organisation are not always easily distinguishable empirically as they are interwoven in and interconnected through the same social phenomena or social practices.

Property rights, the Von Benda-Beckmanns maintained are, first, an important element in ideologies or cultural understandings. They attributed certain functions to property by advocating what property is or should be, for which purposes it should be used and why. In most societies there is not simply one ideology but different and often competing ones. Secondly, legal concepts may themselves contain a component of ideology, but they "tend to be more specific in their definition of the property status of resources and the legal consequences in terms of rights and obligations" (Von BendaBeckmann and Von Benda-Beckmann 1999: 30). As a consequence, in many situations differences emerge between cultural ideals and legal norms. The construction of a private house, for example, will have to meet all kinds of legal requirements in most countries. The third layer consists of "actual social relationships", as distinct from normative regulations, since in many societies substantial discrepancies also exist between actual property relations and legal regulations. Finally, it is necessary to consider the layer of "property practices", both in relation to specific items of property and in relation to actions and processes in which all the rules and practices surrounding property are contested, reproduced and, on occasion, transformed. 
In sum, then, property may mean quite different things at each of these layers and it is important to study their interrelations without assuming that these form a unified compound. What property is at one layer cannot be reduced to what property is at another layer, just as the actual relations between two married people and their daily interactions may be very different from legal rules about marriage. While elements of property relations at the different layers become interconnected in social practices, they have a sufficiently independent character to warrant an examination of their mutual characteristics and interrelationships. The layers form different enabling and constraining factors in people's dealings with property. Each layer within a property regime may change at different speeds and for different reasons.

In addition to the distinction between the layers of social organisation, the Von Benda-Beckmanns (1999: 25) argued that "in all societies some distinction is made between rights to regulate, supervise, represent in outside relations, and allocate property on the one hand, and rights to use and exploit economically property objects on the other". This distinction corresponds to some extent to that drawn by modern lawyers between public and private. Many property rights have both public and private aspects, but the bias of Western academic analysis has induced an exclusive focus on private law to the detriment of the political character of property relations. In the colonial context, including New Zealand, this could mean that chiefs or others were considered private owners of all the land of a social group or community. The Von Benda-Beckmanns (1999: 28) argued that the "reduction of property to property in the private law sense encouraged false comparisons in which the private law notion of 'ownership' and its bundle-characteristics were measured against the totality of socio-political authority and use and exploitation rights in... [non-Western] societies".

The Von Benda-Beckmanns have described their legal anthropological perspective on property as a functional approach, but this term may be misleading since, contrary to its old usage in anthropology, it highlights the political character of property relations. In contrast to the synchronicism of the functionalist school in anthropology, it also emphasises the movement of societies through time. This is particularly apparent in their emphasis on the important distinction between categorical and concretised property relations, the third "layer" of social organisation, which often pass through different historical trajectories. In a more recent paper by the Von Benda-Beckmanns and Wiber (2006), the distinction between categorical and concretised property relations has been developed in more detail, further exemplifying the suitability of their approach for the analysis of the political and historical character of property. 
They argue that, given the social, economic and political significance of valuables, property relations are legally formalised to a high degree in most societies. In this layer, property relations are constructed through general categories of property holders, property objects, rights, duties attached to different forms of property categories, and rules for the appropriation and transfer of property rights. These provide an organisational and legitimating formula for property relations, and also a repertoire to clarify problematic property issues, notably disputes. At this level of legal institutionalisation they refer to property relations as "categorical" (Von Benda-Beckmann et al. 2006: 22).

Property relations, however, are usually also expressed in a more general way, in cultural ideals, ideologies and philosophies. The dominant ones may largely correspond with the legal frameworks, but in many cases property ideals and ideologies are quite different from legal frameworks. Categorical typifications of property relations are particularly different from the social relationships or networks between actual people and organisations with respect to actual valuables, which the Von Benda-Beckmanns summarise with the label "concretized" property relations (1996: 26). Social relations are property relations when interpreted, expressing and giving meaning to general abstract categories of property, property holders, property objects etc. In these processes of interpretation and claiming, these categories are inscribed into social relationships. While there may be disagreement over the "correct" interpretation of property rights and obligations in one legal system, plural legal situations, such as colonial and postcolonial New Zealand, provide particularly rich opportunities to construct different property relations by reference to diverse normative legitimisations for claims and counterclaims as well as procedural avenues to decision-making agencies to pursue them.

Attention to concretised property relations in social analysis is important in order to obtain insight into aspects of property that cannot be derived from categorical concepts. An analysis of concretised property relations reveals which property holders have what, and how many, rights to which concrete property objects. Departing from one property object, e.g., land, an analysis will show what and whose rights pertain to it, while it may also clarify how property objects are distributed over the members of a society, differentiated among class, clans or other tribal groupings, gender or age.

While categorical and concretised property relations cannot be dissociated from each other because concretised property relationships are in various ways shaped by categorical criteria, the Von Benda-Beckmanns and Wiber (2006: 33) asserted that it is important to distinguish them as different social phenomena. Accordingly, they criticise dominant property theory that fails to 
distinguish between categorical and concretised property relations. Although categorical and concretised property relations constitute different constraining and enabling elements for social interaction, in much property theory categories of property rights are routinely assumed to inform people's behaviour and to affect resource allocation or sustainability of natural resources directly, while actual property relations remain largely unnoticed.

Another major problem proceeding from the failure to distinguish between categorical and concretised property relations is the inability to deal with changing property relations. After all, categorical and concretised property relations may also change at different rates while the factors underlying their continuity or discontinuity may also be different. For that reason, too, the patterns of change do not exemplify a clear line of causation. The Von BendaBeckmanns and Wiber (2006: 37-38) distinguished between three different patterns of change. Sometimes a property regime remains unchanged over long periods, while being flexible enough to facilitate different economic and social functions. By the same token, in some situations categorical property systems may change dramatically, while concretised property relations only change marginally or not at all. Finally, under yet other conditions, revised property laws may also bring about significant changes in concretised property relations and economic reorganisations. Recognising the various layers at which property phenomena occur may help to explain all of these variations in historical trajectories of categorical property relations and concretised property relations.

This analytical refinement of the famous metaphor of property as a bundle of rights provides an attractive framework for the analysis of changing property relations in Māori society over the years. All layers of social organisation are to be analysed in their mutual dependence, and none should be privileged over any other. Such an approach is a serious advance over institutional approaches that either put too much emphasis on the categorical legal institutional framework, the so-called rules of the game, or treat institutions as compounds in which norms, rules and behaviour are considered to serve a common purpose and are therefore mixed together. Below I will therefore operationalise the framework set out above in the history of Māori relations to property in both precolonial and postcolonial circumstances.

\section{THE CODIFICATION OF MĀORI PROPERY CATEGORIES}

Property relations, as mentioned above, are basically composed of three main elements: the construction of valuables as property, ideas about social units that hold property rights and obligations, and, finally, the different kinds of relations in terms of rights and obligations. In social circumstances that are characterised by rapid changes it will simultaneously be necessary 
to highlight the temporal dimension of property relations. This paper is principally concerned with land as a valuable to which people, or groups of people, hold proprietary rights. In view of the dynamic and multidimensional concept of property set out above, it should be obvious that the analysis of property relations in Māori society will inevitably be situated in a historical perspective on changes in colonial and postcolonial New Zealand.

In the past, Māori rights to land were so closely intertwined with matters of ancestry and kinship relations that any discussion of Māori property relations should begin with a brief outline of Māori kinship organisation. Since at least the 1840s, Māori kinship groups have been described in terms of a tidy taxonomy of canoes or super-tribes (waka), tribes (iwi), sub-tribes (hapū) and extended families (whānau). It has long been assumed that waka, iwi, hapu $\bar{u}$ and whānau were organised in segmentary hierarchies of waka made up of a number of $i w i, i w i$ made up of a number of hapu, and hapu made up of a certain number of whānau. Analogous with this neat model of social organisation it was assumed that the political organisation of Māori society was also organised in a similar hierarchical structure of command: arikinui, sitting at the apex, commanded the ariki of the tribes, who in turn commanded the rangatira of their various sub-tribes, who were finally believed to be managing the kaumätua or elders of the extended families. This model also tended to assume that sub-tribes lived together in bounded communities occupying discrete stretches of territory with boundaries contiguous with those of other sub-tribes of the same tribe, so that the sum total of the subtribal territories constituted the tribal territory.

This model of Māori socio-political organisation was first drawn up by settlers who had the status of "experts" in the early 19th century, after which it was expanded by the work of officials of the early colonial government (Ballara 1998: 70). It was attractive to government officials since they were looking for a comprehensible and comprehensive hierarchical body politic with which they could enter into negotiations about land purchases. They needed a simplified system of tribal classification as a practical aid in acquiring Māori land in order to solve the pragmatic problem of access to land for the increasing number of settlers arriving in New Zealand.

In the 1860s the rigid model of Māori socio-political organisation was reinforced by the Maori Land Court that was set up to individualise Māori land titles in order to facilitate access to land for European settlers (Ballara 1998: 90). Judges often demonstrated their belief in a strict system of large tribes or nations subdivided into sub-tribes, of which the effective unit was the large tribe, while the sub-tribes were thought to be only the sections to which individuals belonged. Witnesses in court were invariably asked to identify the larger tribe to which the descent groups they were discussing 
belonged. Judges also looked to claimants to set up an ancestor with rights to a particular block of land, whose descendants had occupied it and maintained their control over it to the exclusion of others. ${ }^{3}$ Those ancestors were usually declared to be the eponymous ancestors of single tribes, and judges often believed that the territories of these descent groups were unbroken and could be held by only one "tribe" at a time. Thus, tribes also came to be regarded categorically as the main property holders in Māori society.

Towards the end of the 19th century this model of Māori kinship, leadership and property categories was further authorised by the first generation of serious scholars of Māori society and history. Elsdon Best and Percy Smith incorporated the existing picture of the traditional socio-political structure in their socalled "grand design" of the Māori people (Ballara 1983: 93). The essentialist classification of Māori tribal organisations, chieftainship and property relations was later also adopted by the New Zealand anthropologist Raymond Firth (1959 [1929]) in his doctoral dissertation, after which it became canonised in the anthropology of Māori society until rather recently (Van Meijl 1995).

This model of Māori socio-political organisation, in which $i w i$ are central, is also reflected in its translation as 'tribe', from which all other translations have been derived, and continues to inform contemporary government policy. The Runanga Iwi Act of 1989 was the first statute to codify the iwi model. Although the Act was repealed by the National government after it replaced the Labour government, the spectral presence of $i w i$ remains in the policy for the settlement of Māori claims. Since the early 1990s, both the National and Labour governments have signalled a clear preference for dealing with claimants at an $i w i$ level. In view of the problems with the implementation of the settlement process, and the continuing protests of sub-tribes (hapū) against the exclusive recognition of $i w i$ as negotiating and representative partners of the government, it is important to examine the adequacy of the above model of Māori socio-political organisation in light of historical evidence. Since the pioneering publication by Angela Ballara (1998) on the dynamics of Māori tribal organisations from the arrival of James Cook in 1769 until the end of the Second World War, it has now become possible to compare and contrast categorical property relations as described in legal rules and regulations with concretised property relations in Māori social practices in 19th century New Zealand.

\section{CONCRETISING PROPERTY RELATIONS IN MĀORI SOCIETY}

In the book referred to above, the New Zealand historian Angela Ballara (1998) has demonstrated unequivocally that sub-tribes instead of tribes were the central unit of Māori society. The translation of the Māori concept of $h a p \bar{u}$ as sub-tribe is misleading as it suggests it is derived from a larger, 
encompassing whole, while Ballara showed clearly and unambiguously that hapu $\bar{u}$ were corporate groups of people who thought of themselves as a unit because of their kinship connections through descent. They combined in concrete ways to perform various functions for their self-management, to conduct relations with the outside world, for their defence and in many of their most important economic affairs. Indeed, hapu were independent politically and they acknowledged no higher authority than that of their own chiefs. $I w i$, on the other hand, were not corporate groups, but merely categorical groups, made up of a wide variety of groupings of people who thought of themselves as sharing a common identity based on descent from a remote ancestor. In response to colonial circumstances $i w i$ represented themselves as alternative, more inclusive corporate groups, and only in the recent past have they become the most recognised Māori descent groups.

The relationship between hapu and iwi, between corporate 'sub-tribes' and categorical 'tribes', is also reflected in the rights and obligations regarding the land and natural resources. In this light, it is obvious from the outset that Māori property rights do not concur neatly with European conceptions of property rights. In European societies, title to land provides title holders with virtually all rights in the land, meaning exclusive, undisturbed possession for an indeterminate duration, and the right to encumber it or sell it in perpetuity. In Māori society no one individual or kinship group owned land in the sense that they held virtually all rights in land to the exclusion of other levels of kinship or adjacent groups. Rather, different levels of the hapu exercised different kinds of rights in the same area of land. The right to traverse a stretch of land could extend to the hapu as a whole, but the rights to cultivate particular garden plots within the same area could be exercised by smaller entities, such as individuals, chiefs, smaller groups of kin, extended families or even nuclear families.

These rights were transferred by a number of customary means. Major transfers could occur through war or threat of war, but the rights to specific resources, such as the right to fishing-stands, trees attractive to birds or smaller garden plots, were commonly transferred from, by and to individuals, through gifting and inheritance. Specific rights were transferred in this way to other hapu members and also to members of adjacent groups without necessarily conferring with the hapu as a whole or its ruling chief or chiefs. As a result, Ballara (1998: 195) argued that "the rights of individuals of different hap $\bar{u}$ came to intersect on the ground" and "use-rights became a crazy patchwork". Who had a right to what was perfectly understood, or at least negotiable in terms that people understood, at the time by the members of any community, but use-rights were difficult to define under hapu names in later times. Userights were ordered and prioritised according to well recognised principles, 
but with a marked emphasis on context so that the solution chosen best suited the demands of the moment.

The mere use of natural resources or even occupation of land, however, did not confer a right to dispose of the land permanently. It has been argued frequently that in Māori society, as in most societies, a distinction was made between, on the one hand, rights to use land and exploit natural resources economically, and, on the other hand, rights to alienate, control and allocate property, which in Māori was expressed through the concept of mana that invariably belonged to a communal group of people and could be inherited across generations (Healy 2009). In view of this distinction, then, land in Māori society could and was strictly speaking often occupied without having comprehensive rights. Ballara (1998: 198) even contended that "squatting" was a common phenomenon and was tolerated unless squatters attempted to assert alienation rights. Particularly in areas subject to heavy migration and warfare it was common for an area of land occupied by a hapu to be subject to a number of competing claims of overall rights made by groups that had occupied the land in the past. For a variety of reasons these groups no longer occupied the land, but had in their eyes retained the mana in the land, and therefore they could advance a claim at all times.

The competing claims of alienation rights coupled with the intricate system of overlapping and intersecting rights held by the members of different kinship groupings, makes it difficult to say who "owned" the land, or, for that matter, bodies of water. A major hapu occupying a particular territory undisturbed by war and migration for several generations could hold something akin to ownership in the common law sense, but it was much more common for several different sub-tribes to hold interests in the same area of land. Ownership was furthermore compounded by the factor of time that altered all relationships and degrees of right. Māori descent groups in the 18th and early 19th century were in a constant state of transformation, waxing and waning according to the vicissitudes of customary life. If a group asserting authority over a locality waned over time through political misfortune a new group could replace it. For these reasons, therefore, it makes much more sense to speak of different groups and individual members of descent groups owning a range of different rights in the land, rather than owning land itself (Ballara 1998: 200).

Concretised property relations were thus much more complicated in 19th century Māori society than European codifications of Māori property categories acknowledged. This caused enormous problems when conflicts about property transactions between Māori and Europeans came to light during the second half of the 19th century. In addition, the discrepancy between concretised property relations in 19th-century Māori society and 
European conceptions of Māori property categories also offers a lead for an explanation of contemporary controversies surrounding claims between different levels of the tribal hierarchy (super-tribes, tribes, sub-tribes and large extended families) regarding the settlement of long-standing grievances resulting from the dispossession of Māori land in the past.

\section{RESOLVING COMPETING CLAIMS}

Before the arrival of Europeans, competing claims of land rights were resolved through a variety of customary practices including the use of military force and public pacts. There were, however, no clear-cut rules, and all rights and relationships changed over time. The dominant political force could eventually wane and merge with another more powerful group, or break up through internal conflict and re-allocate the land amongst newly formed groups. In the 1860s, however, this fluid arrangement was frozen in time by the Maori Land Court which prioritised competing claims of right to land by various groups, placing great emphasis on the acquisition of land through conquest, followed up by continuous occupation. The Court also assumed that groups that had migrated to new lands abandoned their ancestral homelands. The Maori Land Court formulated these principles more or less without taking into account the abundant available evidence of more accommodating customary rules (Boast, Erueti, McPhail and Smith 1999: 44).

Interestingly, as mentioned above, the operations of the Maori Land Court along with the increasing number of land sales in the 19th century were of great importance in provoking the delineation of tribes and their gaining prominence over corporate hapu. Initially the Land Court did recognise $h a p \bar{u}$ as the landowning unit in Māori society. It even drew into the official records of the tribal organisation of Māori society the names of thousands of small hapu. Subsequently, however, hapū were regarded as 'sub-tribes' and therefore they were without consultation assigned to a limited number of particular tribes in order to make the overview of Māori tribes more comprehensible. Since many "sub-tribes" had multiple tribal connections, which were also intertwined with kinship principles of cognatic descent and multiple affiliations, the ultimate effect of the operations of the Maori Land Court was to consign many hapū names to oblivion (Ballara 1998: 275).

This process coincided with the growing emergence of tribal groupings or $i w i$ as corporate groups in the course of the 19th century. Following the musket wars among Māori tribes in the early 19th century, and the battles between Māori tribes and the New Zealand government about the access to land in the 1840s through the mid-1860s, tribes gradually took on a more coherent form. Nevertheless, Ballara (1998: 282) firmly concluded that hapu continued to be the primary units of Māori society until at least the mid-20th 
century, when for 90 percent of the Māori population the hapu was still the unit of everyday reality. At the same time, half of the Māori population did not know their tribe. The concept of tribe remained a formal category that people might or might not know, and might or might not make use of.

In spite of these undeniable facts about tribal identification until the mid-20th century, the formation of tribes has continued at the expense of "sub-tribes" since the Second World War. As mentioned above, the process of strengthening of $i w i$ relations began in the 19th century. One of the reasons not yet mentioned, but that proved increasingly important in the 20th century, is that during the second half of the 19th century tribal runanga or councils were set up. They began as meetings to discuss common interests among tribal groupings against the background of the advancement of European settlement in New Zealand, but also to control the irresponsibility shown by some chiefs in the sale of land (Ballara 1998: 287). These tribal runanga would later become the first institutions of the modern tribes. Although in the 19th century runanga may not have been fully effective as tribal councils, the tribal institutions that so emerged contributed to Māori acceptance of the concept of tribe as the wider primary political unit.

In the first half of the 20th century tribal runanga were revived again by the government to examine the injustices of the massive confiscations of land after the wars in the 1860s and other injustices related to the dispossession of Māori of their land in the 19th century. The Crown forced tribes to form corporate bodies in order to be accepted as partners in negotiations about the settlement of land claims. Thus, the formation of tribal organisations received another incentive from government policy. This process would in due course accelerate the constitution of tribes, in spite of the fact that tribal boundaries were still rather fuzzy, which continued to be related to intersecting use rights, and in spite of "sub-tribal" reluctance to accept tribal hegemony (Ballara 1998: 315).

The pressure of the government and the Crown to define certain groups as tribes while excluding others from that status has continued until today. The devolution of powers from the Department of Maori Affairs to new tribal authorities in the late-1980s and the direct negotiations between the Crown and several Māori tribes about the settlement of claims to the Waitangi Tribunal, have produced evidence of similar pressures. In the 1990s, a clear tendency has emerged to redefine $i w i$ as corporate descent groups and as the central unit in Māori society. In some tribes, chiefs gladly accepted this drive from the government, maybe even fostered it, in order to have the separate and independent character of their tribal empire officially recognised (Van Meij1 1997). In other cases, Māori chiefs had no option but to accept the government mode of tribal regulation when preparing or negotiating a 
certain land claim. For any claim to be acceptable and successful, all chiefs had to reconceptualise the social bonds in Māori society in the particular form specified in the legal discourse resulting from the settlement process in contemporary New Zealand. This is the direct result of a new and bounded concept of property which is extended into a situation that was traditionally characterised by intersecting use rights and the absence of a clear, unitary concept of ownership.

In conclusion it might be argued that disputes in contemporary Māori society about the process of settling colonial grievances are caused mainly by a clash between different property regimes, one characterised by intersecting rights and historically without a clear concept of comprehensive ownership, and the other characterised by a bounded conception of ownership, including the right of alienation, introduced into Māori society by European government officials. The discrepancy between these two different property regimes is compounded by two factors. One is the lack of categorisation of property rights and relations in the multidimensional web of linkages between individuals and kinship groupings in the first regime, which is predominantly embedded and concretised in social and political practices. In contrast the second regime is codified in legal forms and categories that correspond neatly with European notions of property. This distinction is further complicated by the fact that the pragmatic conception of use rights to land and natural resources is primarily upheld by lower ranking tribal groupings such as hap $\bar{u}$ and whânau, whereas the more bounded notion of ownership is mainly endorsed by higher ranking tribal units such as $i w i$ and waka. This parallel is not a coincidence since as corporate groups $i w i$ and waka have been shaped largely under the impact of European settlement and colonial and postcolonial policies in New Zealand.

Indeed, tribes have only emerged as powerful organisations in Māori society relatively recently and there can be no doubt that government policies played a decisive role in their institutionalisation (see Van Meijl 2003b). These policies were implemented partly to stipulate the conditions for the return of lands and natural resources that were unjustly dispossessed from Māori in the 19th century. These conditions, however, reconfirmed European views of Māori socio-political organisation that evolved in the course of the 19th century, and which were analogous to a bounded conception of property relations and notions of ownership. Ironically, they are rooted in an essentialist interpretation of socio-political organisation in Māori society of the 19th century, in which the characteristic flexibility of Māori society was 
subordinated in a segmentary model of structural hierarchy. This relatively unambiguous framework for the interpretation of socio-political relationships within Māori society can never do justice to the inherent ambiguity of concretised Māori property relations. After all, it neglects the interests of lower ranking units in the tribal hierarchy, which constituted the core of Māori society in the 19th century and were central in the allocation of use rights to land and other natural resources until the mid-20th century. In the contemporary settlement process, however, their interests are submerged under the authority of tribes, which they acknowledge as their superiors only to the extent that their management of natural resources is not at stake. In sum, it may be contended that although New Zealand may be making great strides in establishing historical justice, it seems imperative to take into account the historical changes in Māori forms of socio-political organisation over time by acknowledging intersecting rights of lower ranking groupings within the hierarchy of Māori kinship organisation lest the settlement process leads to new forms of social injustice within Māori society.

\section{ACKNOWLEDGEMENTS}

Earlier versions of this paper were also presented in Berlin (2011), Cape Town (2011) and Canberra (2011), and I should like to thank Michael Dickhardt, Franz von BendaBeckmann and Nicolas Peterson for inviting me and the participants in the discussions for raising pertinent questions and encouraging me to clarify my argument for an international audience. I am also grateful to two anonymous reviewers for making constructive remarks that have improved this paper. Needless to add, all remaining errors are my own.

\section{NOTES}

1. Wi Parata v. The Bishop of Wellington [1877] 3 NZ Jur (NS) 72.

2. For an introduction to the Waitangi Tribunal, see Sorrenson (1989) and Temm (1990).

3. Les Hiatt (1996: 13-35) has shown that in Australia a similar discussion was held about the relationship between social organisation and property rights in Aboriginal society. 


\section{REFERENCES}

Ballara, Angela, 1998. Iwi: The Dynamics of Maori Tribal Organisation from $\mathrm{c}$. 1769 to c. 1945 . Wellington: Victoria University Press.

Barcham, Manuhuia, 2007. The limits of recognition. In B.R. Smith and F. Morphy (eds), The Social Effects of Native Title Recognition, Translation, Coexistence. Canberra: ANU E Press, pp. 203-14.

Belgrave, Michael, 2005. Historical Frictions: Maori Claims and Reinvented Histories. Auckland: Auckland University Press.

Belgrave, Michael, Merata Kawharu and David Williams (eds), 2005. Waitangi Revisited: Perspectives on the Treaty of Waitangi. Melbourne: Oxford University Press.

Bell, Avril, 2004. 'Cultural vandalism' and Pakeha politics of guilt and responsibility. In P. Spoonley, C. Macpherson and D. Pearson (eds), Tangata, Tangata: The Changing Ethnic Contours of New Zealand. Southbank: Thomson and Dunmore, pp. 89-107.

Boast, Richard, Andrew Erueti, Doug McPhail, and Norman F. Smith, 1999. Maori Land Law. Wellington: Butterworths.

Butterworth, Graham V. and Hepora R. Young, 1990. Maori Affairs: A Department and the People Who Made It / Nga Take Maori: Te Tari me te Hunga na Raatau i Hanga. Wellington: Iwi Transition Agency/Te Tira Ahu Iwi, GP Books.

Byrnes, Gisele, 2004. The Waitangi Tribunal and New Zealand History. Melbourne: Oxford University Press.

Department of Justice, 1995. Crown Proposals for the Settlement of Treaty of Waitangi Claims. Wellington: Department of Justice, Office of Treaty Settlements.

Firth, Raymond, 1959 [1929]. Economics of the New Zealand Maori. Wellington: Government Printer.

Fitzgerald, Eljon, 2004. Development since the 1984 Hui Taumata. In P. Spoonley, C. Macpherson and D. Pearson (eds), Tangata, Tangata: The Changing Ethnic Contours of New Zealand. Southbank: Thomson and Dunmore, pp. 43-58.

Hann, C.M., 1998. The embeddedness of property. In C.M. Hann (ed.), Property Relations: Renewing the Anthropological Tradition. Cambridge: Cambridge University Press, pp. 1-47.

Healy, Susan, 2009. Tuku Whenua as customary land allocation: Contemporary fabrication or history fact? Journal of the Polynesian Society, 118 (2): 111-34.

Hiatt, L.R., 1996. Arguments about Aborigines: Australia and the Evolution of Social Anthropology. Cambridge: Cambridge University Press.

Hofmann, Daniel Alexander, 2009. Virtually Tribal / Tribally Virtual: Shareholders in Indigeneity. Unpublished PhD thesis, University of Otago, Dunedin.

Humphrey, Caroline and Katherine Verdery, 2004. Introduction: Raising questions about property. In K. Verdery and C. Humphrey (eds), Property in Question: Value Transformation in the Global Economy. Oxford: Berg, pp. 1-25.

Kahotea, Des Tatana, 2005. Rebel Discourses: Colonial Violence, Pai Marire Resistance and Land Allocation at Tauranga. Unpublished PhD thesis, University of Waikato. 
Kawharu, I.H., 1977. Maori Land Tenure; Studies of a Changing Institution. Oxford: Oxford University Press.

Kawharu, I.H. (ed.), 1989a. Waitangi; Maori and Pakeha Perspectives of the Treaty of Waitangi. Auckland: Oxford University Press.

Kawharu, I.H. 1989b. Appendix. In I.H. Kawharu (ed.), Waitangi; Maori and Pakeha Perspectives of the Treaty of Waitangi. Auckland: Oxford University Press, pp. 316-21.

Kolig, Erich, 2004. Deconstructing the Waitangi Treaty narrative: Democracy, cultural pluralism, and political myth making in New Zealand/Aotearoa. Sites: A Journal of Social Anthropology and Cultural Studies, 1 (2): 84-118.

Lashley, Marilyn E., 2000. Implementing treaty settlements via indigenous institutions: Social justice and detribalization in New Zealand. The Contemporary Pacific, 12 (1): 1-55.

Matiu, McCully and Margaret Mutu, 2003. Te Whaanau Moana: Ngaa Kaupapa me ngaa Tikanga / Customs and Protocols. Auckland: Reed.

McHugh, Paul, 1991. The Maaori Magna Carta: New Zealand Law and the Treaty of Waitangi. Auckland: Oxford University Press.

Metge, Joan, 1986. In and Out of Touch: Whakamaa in Cross Cultural Context. Wellington: Victoria University Press.

Muru-Lanning, Marama, 2011. The analogous boundaries of Ngaati Mahuta, WaikatoTainui and Kiingitanga. Journal of the Polynesian Society, 120 (1): 9-41.

Oliver, W.H., 2001. The future behind us: The Waitangi Tribunal's retrospective utopia. In A. Sharp and P. McHugh (eds), Histories, Power and Loss: Uses of the Past - A New Zealand Commentary. Wellington: Bridget Williams, pp. 9-29.

Orange, Claudia, 1987. The Treaty of Waitangi. Wellington: Allen and Unwin and Port Nicholson.

Poata-Smith, E.S. Te Ahu, 2004. The changing contours of Maori identity and the Treaty settlement process. In J. Hayward and N.R. Wheen (eds), The Waitangi Tribunal: Te Roopu Whakama i te Tiriti o Waitangi. Wellington: Bridget Williams, pp. 168-83.

Pocock, J.G.A., 2000. Waitangi as mystery of state: Consequences of the ascription of federative capacity to the Maori. In D. Ivison, P. Patton and W. Sanders (eds), Political Theory and the Rights of Indigenous Peoples. Cambridge: Cambridge University Press, pp. 25-35.

Rata, Elizabeth, 2000. A Political Economy of Neotribal Capitalism. Lanham: Lexington.

2003. Late capitalism and ethnic revivalism. Anthropological Theory, 3(1): 43-63.

Sharp, Andrew, 1997a. Civil rights, amelioration, and reparation in New Zealand. In M. Brown and U. Ganguly (eds), Government Policies and Ethnic Relations in Asia and the Pacific. Cambridge, Mass./London: Massachusetts Institute of Technology Press, pp. 421-56. 1997b. Justice and the Maori: The Philosophy and Practice of Maori Claims in New Zealand since the 1970s. Auckland: Oxford University Press. 
2003. Traditional authority and the legitimation crisis of 'urban tribes': The Waipareira case. Ethnologies comparées, (6). Retrieved from the World Wide Web: http://alor.univ-montp3.fr/cerce/revue.htm.

2004. The trajectory of the Waitangi Tribunal. In J. Hayward and N.R. Wheen (eds), The Waitangi Tribunal: Te Roopu Whakama i te Tiriti o Waitangi. Wellington: Bridget Williams Books, pp. 195-206.

Sorrenson, M.P.K., 1989. Towards a radical reinterpretation of New Zealand history: The role of the Waitangi Tribunal. In I.D. Kawharu (ed.), Waitangi: Maori and Pakeha Perspectives of the Treaty of Waitangi. Auckland: Oxford University Press, pp. 158-78.

Temm, Paul, 1990. The Waitangi Tribunal: The Conscience of the Nation. Auckland: Random Century.

van Meijl, Toon, 1995. Maori socio-political organization in pre- and proto-history: On the evolution of post-colonial constructs. Oceania, 65 (4): 304-22.

1997. The re-emergence of Maori chiefs; 'Devolution' as a strategy to maintain tribal authority. In G.M. White and L. Lindstrom (eds), Chiefs Today: Traditional Pacific Leadership and the Postcolonial State. Stanford: Stanford University Press, pp. 84-107.

2003a. Conflicts of redistribution in contemporary Māori society: Leadership and the Tainui settlement. Journal of the Polynesian Society, 112 (3): 260-79. 2003b. Maori tribal organisations in New Zealand history: From neglect to recognition, and the implications for the assimilation policy. Ethnologies comparées, (6). Retrieved from the World Wide Web: http://alor.univ-montp3. $\mathrm{fr} / \mathrm{cerce} /$ revue.htm.

2006. Who owns the fisheries? Changing views of property and its re-distribution in postcolonial Maori society. In F. von Benda-Beckmann, K. von Benda-Beckmann and M. Wiber (eds), Changing Properties of Property. New York: Berghahn, pp. 170-93.

von Benda-Beckmann, Franz and Keebet von Benda-Beckmann, 1999. A functional analysis of property rights, with special reference to Indonesia. In T. van Meijl and F. von Benda-Beckmann (eds), Property Rights and Economic Development: Land and Natural Resources in Southeast Asia and Oceania. London: Kegan Paul International, pp. 15-56.

von Benda-Beckmann, Franz, Keebet von Benda-Beckmann and Melanie Wiber, 2006. The properties of property. In F. von Benda-Beckmann, K. von BendaBeckmann and M. Wiber (eds), Changing Properties of Property. New York: Berghahn, pp. 1-39.

Waitangi Tribunal, 1998. Te Whanau o Waipareira Report. Waitangi Tribunal Report WAI 414. Wellington: GP Publications.

Ward, Alan, 1999. An Unsettled History: Treaty Claims in New Zealand Today. Wellington: Bridget Williams Books.

Waymouth, Lyn, 2003. The bureaucratisation of genealogy. Ethnologies comparées, (6). Retrieved from the World Wide Web: http://alor.univ-montp3.fr/cerce/ revue.htm. 
Webster, Steven, 1975. Cognatic descent groups and the contemporary Māori: A preliminary reassessment. Journal of the Polynesian Society, 84 (2): 121-52. 1998. Patrons of Mãori Culture: Power, Theory and Ideology in the Mãori Renaissance. Dunedin: University of Otago Press.

2002. Māori retribalization and Treaty rights to the New Zealand fisheries. The Contemporary Pacific, 14 (2): 341-76.

\begin{abstract}
This article examines controversies around the representation of Māori in the process that aimed at settling colonial grievances about the dispossession of their land in the 19th century. The analysis of contemporary questions is situated in a historical perspective on the nature of property rights in the past: who used to own the land then and what does it mean now? A legal anthropological perspective is used to disentangle historical and contemporary concerns in order to refine the quest for the right balance between historical justice and social justice.
\end{abstract}

Keywords: New Zealand Māori, legal anthropology, change, property rights, settlement process 